CZU:821.135.1-34.09

https://doi.org/10.52505/filomod.2021.15.22

\title{
CONSUMUL ATIPIC AL MÂNCĂRII ÎN BASMELE LUI B. P.-HASDEU
}

\author{
Olesea GîRLEA \\ Institutul de Filologie Română „B. P.-Hasdeu” al MEC
}

Rezumat. Articolul se axează pe dominanta digestivă a basmelor lui B. P.-Hasdeu, în special pe elementele gastronomice, care devin parte a ficțiunii fără de care ar fi imposibil derularea firului narativ: ingurgitarea eroului, hrănirea intermediarului care asigură conexiunea dintre lumea pământească și cea de dincolo, depășirea obstacolelor prin consumul exagerat al bucatelor, fertilizarea prin intermediul alimentelor, canibalismul, sacrificarea propriului corp constituie principalele momente analizate.

Cuvinte cheie: ritual, sacrificiu, ingurgitare, marginea lumii, gastronomie

Abstract. The article focuses on the digestive dominance of B .P.-Hasdeu's fairy tales, especially on the gastronomic elements, which become part of fiction without which it would be impossible to unfold the narrative thread: swallowing the hero, feeding the intermediary who ensures the connection between the earthly world and the afterlife, overcoming obstacles through excessive consumption of food, fertilization through food, cannibalism, the sacrifice of one's own body are the main moments analyzed.

Keywords: ritual, sacrifice, swallowing, the edge of the world, gastronomy

Într-o primă etapă a cercetării noastre vom observa că imaginarul gastronomic din basme se detașează de gândirea tranzitivă, astfel raportul dintre subiect/obiect pune problema reprezentării dintre real și simbolic, dintre ceea ce cunoaștem despre alimente și ceea ce derivă din firul narativ al fabulei.

Gilbert Durand în studiul său despre imaginar intitulat Structuri antropologice ale imaginarului pornește de la ideea tradiției din Occident bazată pe datele arhetipologiei, prin care se dă ,,plăcerilor burții” o interpretare mai mult sau mai puțin tenebroasă sau cel puțin nocturnă. Aceste repere ale gastronomicului îi dictează filozofului francez sciziunea imaginarului în două direcții pe care le numește regimul nocturn și regimul diurn al imaginarului. Ne interesează în mod special regimul nocturn, pe care filozoful francez îl subîmparte în dominanta digestivă și dominanta ciclică ,cea dintâi subsumând tehnica recipientului și cea a habitatului, valorile alimentare și digestive, sociologia matriarhală și nutritivă, cea de a doua grupând tehnica ciclului a calendarului agricol și a industriei textile, simbolurile naturale sau artificiale ale întoarcerii, miturile și dramele astro-biologice" (Durand, 1997, 70). 
Ne vom referi la câteva elemente surprinse la G. Durand cu referire la dominanta digestivă a regimului nocturn al imaginarului, care sunt în strânsă conexiune cu dominanta digestivă a basmelor lui B. P.-Hasdeu. Unul din aceste elemente este coborârea digestivă și schema înghițirii, căci „orice valorificare a coborârii este legată de intimitatea digestivă, de gestul ingurgitării" (Durand, 1997, 247), coborârea este strâns legată de interiorul devenirii; înghițirea/ingurgitarealîncastrarea care ,nu deteriorează, foarte adesea valorifică sau chiar sacralizează" (Durand, 1997, 254) și care are drept efect minimalizarea, universalitatea credinței în maternitatea pământului (așa numitul pântece matern) o surprindem și în basme acolo unde eroul pleacă în căutarea inițierii și a formării sinelui.

Voi analiza în continuare câteva basme preluate din volumul 19 (folclor literar, proză populară) a lui B. P.-Hasdeu din seria Scrieri, apărut la editura Știința în anul 2020. În special voi face referire la basmele, legendele, povestirile fantastico-superstițioase în care apar dominate gastronomice inserate în corpul textului, funcția cărora nu este cea gastronomică (de satisfacere a apetitului burții), ci de element de construcție al ficțiunii fără de care este imposibilă derularea firului narativ.

În basmul Dunca Viteazul, băutoriul țarei cronotopul benefic alternează cu cel malefic și sunt reprezentați prin indicii cromatice ambivalente. Voinicul părăsește lumea albă pentru lumea neagră din imboldul de a cauta fetele împăratului care au fost furate de zmei. Menționez că în interpretarea Laviniei Bârlogeanu, autoarea studiului Diavolul în viziuni povești și vise (2014) poveștile și basmele sunt „modalități practice de a acționa în fața răului" (Bârlogeanu, 2014, 169), autoarea explică faptul că zemii prezintă răul atins de gigantism pe care trebuie să-1 învingă eroii. Proba milosteniei, cronotopul podului și al fântânii sunt definitorii pentru inițierea și devenirea protagonistului. După înfrângerea zmeilor, fetele de împărat sunt scoase din lumea neagră în lumea albă cu ajutorul „,huzurdăului”, iar Dunca este abandonat în lumea neagră de către con-drumeții săi invidioși și profitori.

Isprava salvării puilor de pajură din gura balaurului cu nouă capete îi aduc recunoștința mamei pajură, care de șase ani scoate zadarnic pui, însă aceștia sunt înghițiţi de balaur. Temerea puilor de pajură pentru viața voinicului este adeverită de fapte reale, mama lor îl înghite pe eroul salvator. Ingurgitarea și vomarea eroului ${ }^{1}$, proces tipic disfuncției alimentare, are în basm semnificații pozitive la superlativ, pentru că eroul iese din intestinele pajurii ,mult mai mândru și mai frumos de cum a fost" (Hasdeu, 2020, 13). Ceea ce înghite pajura poate fi readus în lume din „uterul gestant și hrănitor” (Bârlogeanu, 2014, 172), este un principiu feminin cu rol de hrănire și de conservare a vieții. Astfel se produce reînnoirea vieții prin taina trecerii prin moarte pentru a reveni din nou la viață.

1 „Văzând pajura că prea tare s-au supărat puii pentru că 1-a înghițit, numai decât 1-a ignit îndărăt, cu mult mai mândru și mai frumos de cum a fost” (Hasdeu, vol. XIX, 13) 
Abundența consumului gastronomic în scopul depășirii obstacolelor face parte din tipicul intrigii basmelor, astfel Dunca Viteazul (personajul din basmul amintit mai sus) reușește să părăsească lumea neagră pe spatele pajurii, pe care o hrănește cu merindele pregătite de fetele împăratului 6 cuptoare de pită, trei boi fripți, o bute cu vin'2. Momentul final al călătoriei însoțită de festinul gastronomic - garant al parcurgerii drumului lung - este însoțit de finisarea cărnii, pe care voinicul o suplinește cu o parte din talpa piciorului său pe care i-o dă drept gustare pajurii. Consumul de carne omenească de către animale pentru a (re)căpăta forțele necesare este un element compozițional specific al unor basme, care descriu parcurgerea unei traiectorii sinuoase. Astfel parcurgerea imposibilului drum devine posibilă și este determinată de consumul atipic prin care se produce sacrificiul de sine, prin el se produce eliberarea din lumea subterană.

În același basm mâncarea devine un mijloc de identificare al protagonistului, care pune inelul de aur al fetei mari a împăratului în mijlocul mălaiului cu intenția de a fi găsit de aceasta. Bijuteria îi reamintește fetei de cel care a salvat-o din lumea neagră și astfel este restabilită dreptatea, iar impostorii sunt pedepsiţi.

În basmul Fetele de impărat, apărut în aceeași culegere, Scrieri, vol. XIX al lui B. P.-Hasdeu, firul de piper ingurgitat ${ }^{3}$ este echivalent al fertilizării naturale din care rezultă apariția unui copil. Incă S. Freud a încercat să explice existența unui libido puternic la copil în procesul consumului hrănii/alăptării. Așadar mâncarea, în unele basme populare, mai ales în cele în care lipsește componenta masculină a cuplului e substituită prin indicii gastronomice cu funcție reproductivă. Numele copilului, Chipăruș Viteazul, e direct proporțional cu drumul inițiatic pe care-l parcurge până în buricul pământului în căutarea surorilor sale răpite de zmei. Iar ieșirea din acest cronotop malefic va fi asigurată de Muma Pădurii, pe care viteazul o va hrăni cu „,nouă care de carne". Abundența exagerată a merindelor care asigură asemeni combustibilului forțele vitale în procesul deplasării e urmată de consumul rapid al acestora aproape de finisarea drumului, pe care eroul îl substituie cu o parte de carne din corpul său ${ }^{4}$. Cele nouă care cu carne consumate în timpul călătoriei redau complexitatea itinerarului și distanța enormă parcursă.

Aceeași idee a consumului ca echivalent al fertilizării naturale în cazul lipsei componentei masculine a cuplului o întâlnim și în basmul Povestea lui Măzăricăa, reieșind din titlu, deducem că fertilizantul este asigurat de această dată, de firul de mazăre. Protagonistul devine prin această concepere

2 „Când pajura făcea cu capul în dreapta, atuncea-i da pită, când făcea cu capul în stânga-i da carne; iar când făcea cu capul îndărăt, 'i da vin de băut” (Hasdeu, vol. XIX, 13)

„Într-una din zile, pe când această femeie sta la masă și foarte tristă, i se arătă pe masă un fir de piper, pe care, luându-1, 1-a înghițit, din care a și simțit că a rămas grea" (Hasdeu, vol. XIX, 16).

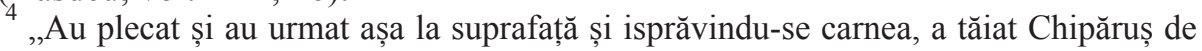
la talpa lui (de aceea se zice că omu are sec la talpă) şi aşa 1-a dat afară (Hasdeu, vol. X́ IX, 2020, 16). 
neverosimilă un erou al misterului, care parcurge drumul inițiatic în lumea cealaltă, unde este scos de pajură (căreia Măzărică i-a salvat puii de Balaur) acesta îi pregătește un festin impresionant ce constă din „99 de vase pline cu carne și 99 de vase pline cu apă”. În mod lesne de dedus, acestea merinde nu sunt suficiente pentru a parcurge drumul inițiatic până la capăt, iar când merindele se sfârșesc, călătorul taie o parte din pulpa piciorului său pentru a finisa manevra de ieșire din lumea de dincolo. Cronotopii marginii lumii, lumii de dincolo, a intrărilor și ieșirilor sunt definitorii și de nelipsit în derularea subiectului basmului. Deseori ieșirea din lumea de dincolo este asigurată de un intermediar și poate fi condiționată prin sacrificiul de sine, așa cum se întâmplă atunci când personajul taie o parte din corpul (talpa/pulpa piciorului) său pentru a hrăni pasărea - care are rol de „taximetrist” între lumea pământeană și cea de dincolo.

Aspecte canibalice ale mâncării le depistăm în basmul Muma-Pădurii din aceeași culegere de basme adunată de B. P.-Hasdeu. Fata care parcurge drumul spre Muma Pădurii (la solicitarea acesteia) în intenția de a o ajuta la lucru este salvată de drumeții pe care-i întâlnește în cale și care-i oferă obiecte cu puteri magice (piatra, peria, acul). Casa Mumei-Pădurii lângă care stă un cap de om înfipt în par nu deconspiră iniţial răutatea și stilul alimentar al gazdei, care pretinde că țeasta că e o „căpățână de cal”, la fel și pentru oamenii legați sub pat, femeia malefică are explicații convingătoare „sunt niște gâște, clocesc". Fata este salvată de un șoarece care are menirea de erou-salvator care deconspiră răutatea Mumei-Pădurii. Obiectele magice aruncate peste cap, fac impracticabil drumul Mumei-Pădurii, iar replica din final prin care deconspiră firea malefică și preferințele alimentare ale femeii ${ }^{5}$.

Ingurgitarea și vomarea personajelor - procedeu alimentar prin care este reactivat ciclul morții și al vieții, are conotația pedepsei în povestea Iov Impăratul. Intriga poveștii este declanșată de bunul Dumnezeu, care-1 întreabă pe Iov când ar vrea să fie mai fericit în anii tinereții sau în cei ai bătrâneții. Pentru că Iov alege varianta din urmă, Dumnezeu îi trimite o serie de încercări cumplite în tinerețe: o boală nesuferită peste vitele și slugile lui, bube peste corpul lui Iov, dracii ca ispită a soției sale, turcul hoț care-i răpește soția, înghițirea copiilor săi de către un lup și un pește. La capătul disperării și al răbdării, Iov devine ca prin minune împărat în Țara turcului, iar din acest moment își întregește și mărește familia pierdută, având parte de împlinirea spirituală solicitată în anii senectutiii. Curios este faptul că odată scoși din intestinele acestor animale, copiii săi ies mai frumoși decât erau inițial ${ }^{6}$. Astfel se produce reînnoirea și perpetuarea vieții protagoniștilor.

\footnotetext{
${ }^{5}$ Ea n-a voit. Și de necaz și de ciudă, a murit zicând:

- Surată, surată, credeam că te-oi mânca, da 'm-ai mâncat tu pe mine” (Hasdeu, vol. XIX, 2020, 36).

${ }^{6}$ Copii lui Iov pe care-i înghițiseră lupul și peștele, încă scăpară cu viață. Pentru că un vânător a împușcat lupul și a scos copilul viu din el, cu mult mai voinic și mai frumos de cum a fost; iară un pescar a prins peștele și, iară, a scos copilul întreg din el, cu mult mai voinic și mai frumos de cum a fost înainte. (Hasdeu, vol. XIX, 103).
} 
În volumul XVIII în special în bocete, descântece plantele și alimentele precum: urzica, busuiocul, laptele, mirul, vinul, tămâia sunt asociate funcției magice a cuvântului, ele susțin procesul de persuasiune a ritualului de vindecare și alungare a bolii, de sporire a belșugului.

În construcția narativă a basmelor alimentele au un rol esențial în derularea acțiunii, ele sunt deseori mijloace de depășire și trecere a obstacolului. În unele basme, alimentele constituie un indiciu al funcției reproductive și sunt puternic ancorate în semnificația numelui personajului. Funcția digestivă propriu zisă a alimentelor trece pe locul doi în favoarea susținerii procesului de persuasiune a ritualului, a sacrificiului de sine și a reînnoirii vieții.

\section{Referințe bibliografice:}

1. PETRICEICU-HASDEU, Bogdan Scrieri, vol. XVIII, Folclor literar (1). Folclor tradițional în versuri.ediție critică de I. Oprișan, Chișinău, Știința, 2020.

2. PETRICEICU-HASDEU Bogdan, Scrieri, vol. XIX, Folclor literar (2). Proză populară, ediție critică de I. Oprișan, Chișinău, Știința, 2020.

3. DURAND, Gilbert Structuri antropologice ale imaginarului, trad. de Aderca Marcel și Radu Toma, București, Univers, 1997.

4. BÂRLOGEANU, Lavinia Bârlogeanu, Diavolul în viziuni, povestiri și vise, București: Nemira, 2014.

Notă: Articolul a fost realizat în cadrul proiectului de cercetare 20.80009.1606.03 Contexte socioculturale autohtone şi interconexiuni europene în creaţia populară şi literatura cultă din Basarabia (sec. XIX până în prezent), Institutul de Filologie Română „B. P.-Hasdeu” al MEC. 